\title{
The Effect of the Realistic Mathematics Education Approach: Meta-Analysis of the Measured Mathematical Ability Angle
}

\author{
Maximus Tamur ${ }^{1, *}$ Valeria S kurnila $^{2}$, Emilianus Jehadus ${ }^{3}$, Adi Nurjaman ${ }^{4}$, Kanisius \\ Mandur $^{5}$ and Sabina Ndiung 6
}

1,2,3,5,6 Universitas Katolik Indonesia Santu Paulus Ruteng, Indonesia

${ }^{4}$ Institut Keguruan dan Ilmu Pendidikan Siliwangi, Cimahi, Indonesia

*Corresponding author. Email: maximustamur@unikastpaulus.ac.id

\begin{abstract}
Although the literature has presented the overall effect of the RME approach, no specific studies have analyzed its relationship to the type of mathematical ability being measured. This meta-analysis study was conducted to measure the overall effect of RME and explore its relationship to types of mathematical ability and consider its implications. ERIC databases, sage publishing, springer publishing, and google scholar were examined to achieve relevant research. The study analyzed 54 effect sizes from 38 individual studies that have been published in the past two decades, and a total of 4798 students were involved. Random effects models with 95\% confidence intervals (CIs) were estimated, and statistical calculations used the Comprehensive Meta-Analysis (CMA) program. Based on the analysis, it was found that the overall effect size of the study was 0.97 . The analysis results show that the implementation of RME has a considerable positive impact on students' mathematical abilities. The moderator analysis revealed that the implementation of RME has a massive impact on the low or medium-level cognitive domains. Finally, the research implications are discussed and provide critical information for future RME implementation and as a basis for future meta-analysis studies.
\end{abstract}

Keywords: Realistic Mathematics Education, Meta-analysis, Mathematics ability, Effect size.

\section{INTRODUCTION}

The past two decades have shown great interest in implementing the realistic mathematics education (RME) approach. RME is a teaching theory specific to the mathematical domain, which has been developed in the Netherlands [1]. RME is a learning process that makes real situations a context and a learning stimulus [2]-[5] helping teachers to teach mathematics to students and successfully improve their math skills [6], [7]. This recommendation sparked a flurry of individual studies on the effectiveness of RME.

Hundreds of quantitative studies on the effects of RME have been presented in the literature, but the analysis results are inconsistent. The analysis results from [8]-[10] for example, found that using the RME approach was effective in students' mathematical abilities. Meanwhile, [11], [12] reported that students' ability in the RME class was not better than the ability of students in conventional classrooms because these conflicting findings have triggered a meta-analysis study to reconcile the findings and produce more objective results [13].

Meta-analysis studies of the overall effects of RME contribute to providing literature on mediators that may need to be considered in the future. Several previous meta-analyses in mathematics education have examined the overall effects of student-centered learning [14], contextual teaching-learning (CTL) [15]-[17] and problem-based learning [18]-[23]. But to date, only [24] have conducted a meta-analysis of the overall effects of RME by analyzing 95 effect sizes from 72 individual studies. The study does not include individual studies on RME from abroad. On the other hand, analyzing foreign and domestic studies is necessary to provide a more comprehensive meta-analysis and clear assessment [25]. Besides, this study has not analyzed the study's effect size in terms of differences in measured variables. 
This study extends previous research that focused on determining the overall effect of RME and examines whether differences in measured variables affect the studies' effect sizes. Besides, the research publication bias is presented to provide basic ideas for further research and mapping the strengths of RME. The findings of this study provide accurate information to educators in implementing further RME

\section{METHOD}

The research method uses a meta-analysis to combine a group of individual studies to integrate the findings [26], [27], [28], [29]. This research begins by determining the inclusion criteria, collecting and coding variables, and statistical analysis [30], [31].

\subsection{Inclusion Criteria}

According to the research objectives, the articles deemed suitable for inclusion in the analysis are based on the following criteria:

(a) The articles analyzed were identified from national and international journals. Each study must report the effect of RME on students' ability to use experimental research methods. RME studies using qualitative methods, surveys, and developments were excluded from the analysis. For example, [32] reveals how $\mathrm{RME}$ is configured in prospective mathematics teachers' minds. Although they involved 32 subject teacher candidates, this study did not involve a control class as a comparison because it was excluded from the analysis.

(b) Publication in at least the last two decades (20002020).

(c) Selected articles are published in English. Studies that did not comply with these provisions were excluded from the analysis.

(d) Study participants level from elementary school to university level. Studies conducted at the preschool level were excluded from the analysis.

(e) Studies that apply a test method that meets the requirements for assessing mathematical abilities. Review studies are excluded. For example, [24] reviewed the effectiveness of RME in the past 60 years. Although they evaluated the effects of RME, they did not carry out experiments to adapt the data.

(f) Each study must report statistical information for the effect size transformation (ES). Studies that only report normalized gain results without including standard deviation and sample size data were excluded from the analysis.

\subsection{Data collection}

An online database which includes ERIC (https://eric.ed.gov/), $\quad$ SAGE Publishing (https://journals.sagepub.com/), and Google Scholar (https://scholar.google.com/) is defined as a data search location. Data selection used the PRISMA (Preferred Reporting Items for Systematic Reviews and MetaAnalyzes) protocol, starting with identifying 248 individual studies. Based on the screening stage and eligibility, 38 individual studies were included in the analysis. However, there was a study involving more than one comparison group, so that 54 ES were analyzed.

This study uses a coding form as a data collection instrument. This form was developed to extract information from individual studies into numerical data, including title, year of study, country of study, and variables measured. To disarm the threat of external validation than two independent coders were involved. The reliability test uses the Cappa Cohen coefficient ( $\kappa$ (7)), which is a vital statistic for testing the level of agreement among coders [33]. Cohen's kappa formula is;

$$
\kappa(7)=\frac{\operatorname{Pr}(a)-\operatorname{Pr}(e)}{1-\operatorname{Pr}(e)}
$$

$\operatorname{Pr}$ (a) represents an observable agreement, and $\operatorname{Pr}(\mathrm{e})$ represents a coincidence agreement. A value of 0.85 or greater is pre-determined to be considered high. The agreement level in the study is 0.87 , which means there is a substantial match between coders. Thus the data in this meta-analysis are reliable.

\subsection{Inclusion Criteria}

The unit of analysis in this study is the effect size (ES), which reflects the magnitude of the influence of RME on students' mathematical abilities. The ES transformation uses Hedges' g equation, while the interpretation uses classification [34]; that is, less than 0.2 (negligible), between 0.2 and 0.5 (small effect), between 0.5 and 0.8 (moderate effect), between 0.8 , and 1.3 (large effect), and more than 1.3 (very large effect). The estimation method uses a random-effect model because it does not assume that all the true effect estimates are the same [35]. Statistical calculations for the heterogeneity test were performed using the CMA. The null hypothesis (h0), which states that all research results are the same (homogeneous), is rejected if the pvalue $<0.05$, which means that the ES between studies or study groups is different or may not measure the same parameters [36]. 


\section{RESULT AND DISCUSSION}

\subsection{Overall Analysis}

First, this study was conducted to determine the magnitude of the overall effect of RME. Figure 1 presents the research forest plot

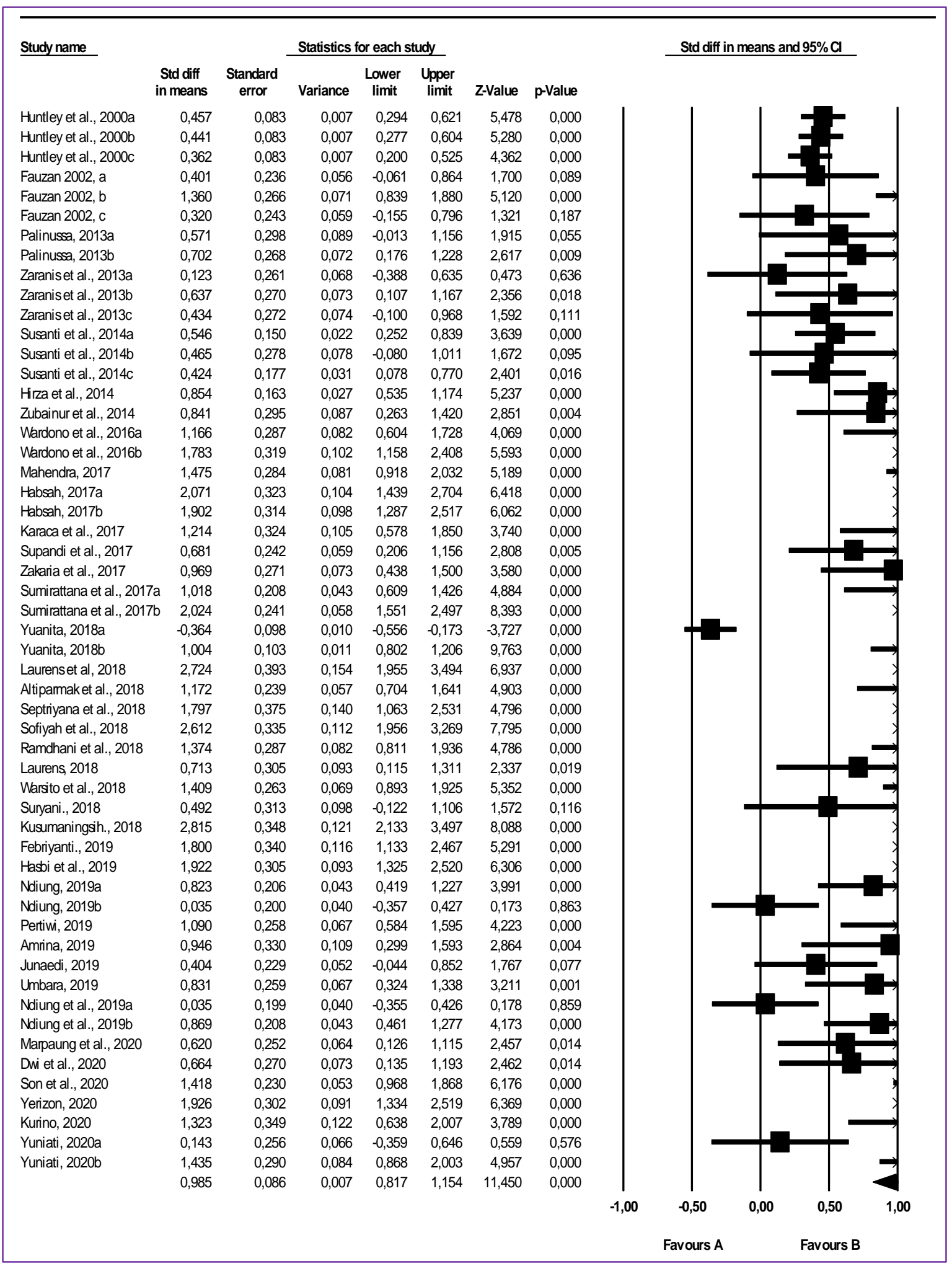

Figure 1. Research forest plots 
Figure 1 illustrates the inconsistent ES RME, which reflects the mediator's influence on students' mathematical abilities. Table 1 shows the comparison of the research results according to the estimation method.

Table 1. Short cut keys for the template

\begin{tabular}{|c|c|c|c|c|c|c|c|c|}
\hline \multirow[t]{2}{*}{ Model } & \multirow[t]{2}{*}{$\mathrm{N}$} & \multirow[t]{2}{*}{ Hedges's g } & \multirow{2}{*}{$\begin{array}{c}\text { Standard } \\
\text { error }\end{array}$} & \multicolumn{2}{|c|}{$95 \%$ Confidence Interval } & \multirow[t]{2}{*}{ Q } & \multirow[t]{2}{*}{$\mathrm{P}$} & \multirow[t]{2}{*}{ Decision } \\
\hline & & & & Lower & Upper & & & \\
\hline Fixed-effects & 54 & 0.67 & 0.02 & 0.62 & 0.72 & \multirow[t]{2}{*}{487.19} & \multirow[t]{2}{*}{0.00} & \multirow[t]{2}{*}{ Reject $\mathrm{H}_{0}$} \\
\hline Random-effects & 54 & 0.97 & 0.08 & 0.80 & 1.14 & & & \\
\hline
\end{tabular}

When Table 1 was examined, a pond that the p-value $<0.05$, which means the ES distribution is heterogeneous. Thus the estimation method fits into the random-effect model. The weakness of the meta-analysis study is the existence of a publication bus factor, namely the tendency of journals to only publish significant articles, leading to distortion [36], [37], [38]. To check whether there was an effect of publication bias in this study than the study funnel plot in Figure 2 was observed. Resistant to publication bias if the individual ES studies are spread symmetrically [36]. If the 54 ES studies were not completely symmetrical, then the Rosental fail-safe N (FSN) statistic was used to check for publication bias. The formula used is $\mathrm{N} /(5 \mathrm{k}+10)$, where $\mathrm{N}$ is the FSN value, and $\mathrm{k}$ is the number of studies [39]. If the calculation result is greater than 1 , it means that this study's results are resistant to publication bias. Figure 2 presents the research funnel plot.
Figure 2 shows that the ES is not entirely symmetrical in the center of the funnel plot. From the calculation of the $\mathrm{N}$ value calculated as 1459 , it is obtained 2652 / ( $5 *$ $54+10)$, is $4.56>1$. This means that the studies included in this analysis are resistant to publication bias. Thus, no study was lost or needed to be added to the analysis because of publication bias.

\subsection{Results of Analysis of Mediator Variables}

The results included in the meta-analysis show a heterogeneous ES distribution so that the mediator variables which are considered to influence the relationship between the dependent and independent variables should be investigated [40]. According to the second objective of the study, the mediator under study is the variable being measured. Table 2 below is a summary of the analysis results.

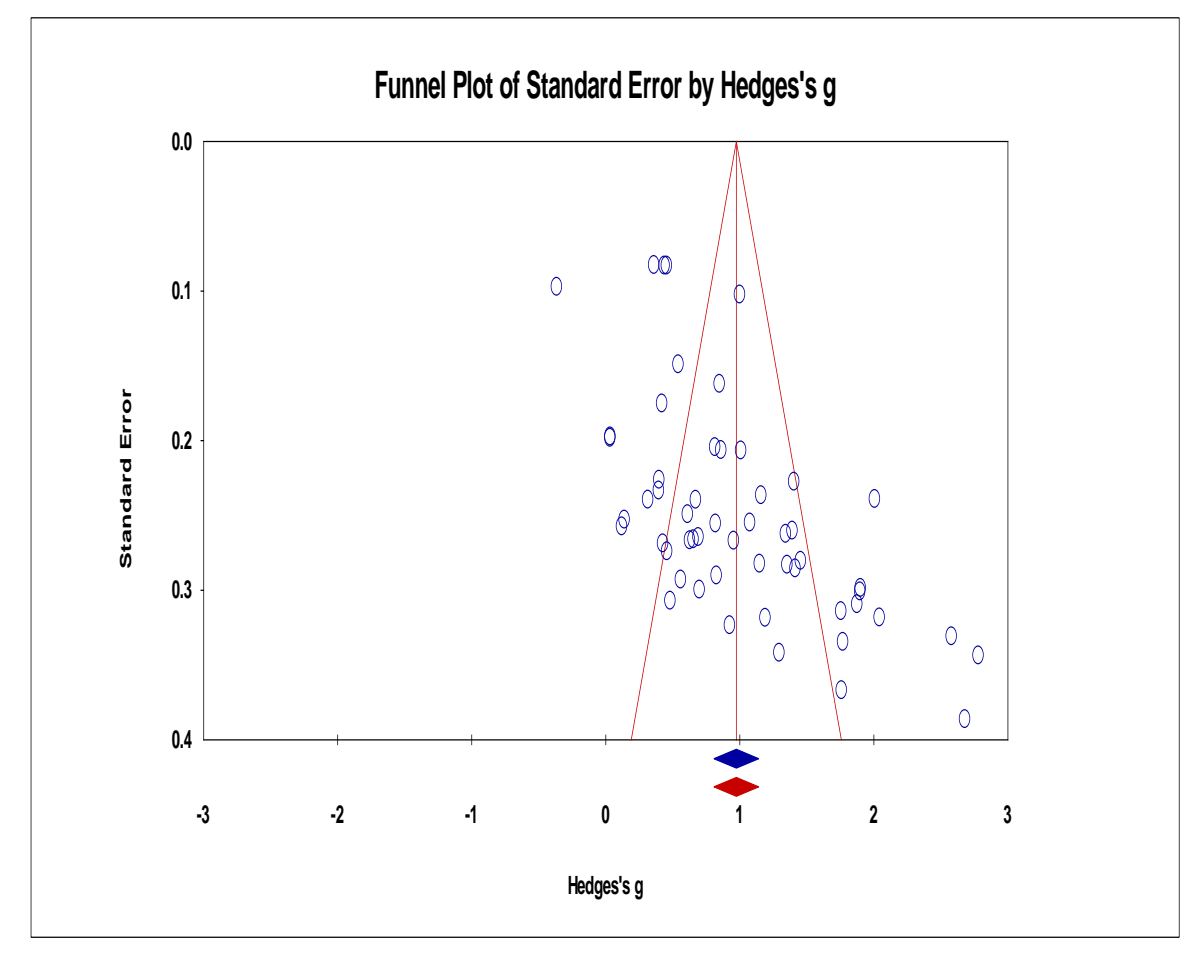

Figure 2. Research funnel plot 
Table 2: Results of Mediator Variable Analysis

\begin{tabular}{|c|c|c|c|c|c|c|c|}
\hline \multirow{2}{*}{$\begin{array}{l}\text { Mediator } \\
\text { Variable }\end{array}$} & \multirow{2}{*}{ Group } & \multirow{2}{*}{$\mathrm{N}$} & \multirow{2}{*}{ Hedge's g } & \multicolumn{3}{|c|}{ Heterogeneity } & \multirow{2}{*}{ Decision } \\
\hline & & & & $\mathrm{Q}$ & $\mathrm{df}(\mathrm{Q})$ & $\mathrm{P}$ & \\
\hline \multirow{11}{*}{$\begin{array}{l}\text { The variable } \\
\text { being } \\
\text { measured }\end{array}$} & Think mathematically & 4 & 0.49 & \multirow{11}{*}{186.91} & \multirow{11}{*}{10} & \multirow{11}{*}{0.00} & \multirow{11}{*}{ Reject $\mathrm{H}_{0}$} \\
\hline & HOTS & 3 & 0.35 & & & & \\
\hline & Intuition & 2 & 0.85 & & & & \\
\hline & Mathematical communication & 2 & 1.91 & & & & \\
\hline & Mathematical literacy & 5 & 0.71 & & & & \\
\hline & numerical ability & 3 & 0.54 & & & & \\
\hline & Mathematical connection & 2 & 1.86 & & & & \\
\hline & comprehension ability & 21 & 0.94 & & & & \\
\hline & mathematical representation & 2 & 1.53 & & & & \\
\hline & Mathematical problem solving & 7 & 0.82 & & & & \\
\hline & Mathematical reasoning & 3 & 1.06 & & & & \\
\hline
\end{tabular}

Based on the random-effects model, it was found that the ES of the whole study was estimated to be 0.97. According to the ES criteria, it can be interpreted that the implementation of RME has a significant impact on students' abilities. This result is supported by a previous meta-analysis conducted by [24] on the effects of RME in Indonesia $(\mathrm{ES}=1.10)$. Related research on CTL's overall effect also supports this finding $(E S=0.87)$ [15]. This study's results are almost similar to reflect the overall learning trend, which makes real-world situations a learning context even though the samples and research periods are different.

The results of the analysis of the mediator variables in Table 2 show that the implementation of RME is related to differences in the measured variables $(\mathrm{Q}=$ 186.91; $\mathrm{P}<0.05)$. The results of the analysis show that the implementation of RME has a significant impact on the ability of mathematical connections $(\mathrm{ES}=1.86)$, mathematical communication $(\mathrm{ES}=1.91)$, mathematical representation $(\mathrm{ES}=1.53)$, and mathematical reasoning $(\mathrm{ES}=1.06)$. Furthermore, the implementation of RME has little impact on mathematical thinking skills and higher-order thinking skills (HOTS). Thus the implementation of RME is not recommended to measure mathematical thinking skills and HOTS. Because in the literature, there is no comparison related to this mediator, it is necessary to carry out further studies involving more individual studies

\section{CONCLUSION}

The analysis results show that the implementation of RME has a large positive impact on students' mathematical abilities. The moderator analysis revealed that the implementation of RME has a large impact on the low or medium-level cognitive domains. However, these findings were only supported by individual studies that were eligible for analysis. Many other studies are similar but do not inform the statistical data needed to transform effect sizes. Subsequent individual studies of the effects of RME need to inform complete statistical data. Besides, to provide a more comprehensive picture, it is necessary to conduct a meta-analysis in the future in which a study with comparisons between countries is identified as a mediator variable.

\section{ACKNOWLEDGMENTS}

I would appreciate James J Lindsay, M Borenstein, and the CMA team at Biostat Englewood USA for all their technical assistance and contributions to the research project. Thanks to the two postgraduate students of the University of Education of Indonesia as coders in this research.

\section{REFERENCES}

[1] M. Van den Heuvel-Panhuizen and P. Drijvers, "Realistic Mathematics Education," in Encyclopedia of Mathematics Education, S. Lerman, Ed. Springer Netherlands, 2014, pp. 521525.

[2] R. C. I. Prahmana, L. Sagita, W. Hidayat, and N. W. Utami, "Two Decades of Realistic Mathematics Education Research in Indonesia: A Survey, "Infin. J., vol. 9, no. 2, pp. 325-340, 2020, doi: 10.1007/978-3-030-20223-1_18.

[3] Z. Zulkardi, R. I. I. Putri, and A. Wijaya, "Two Decades of Realistic Mathematics Education in Indonesia," in International reflections on the Netherlands didactics of Mathematics, ICME-13 Monographs, M. Van den Heuvel-Panhuizen, Ed. Cham: Springer, 2020, pp. 325-340.

[4] M. Tamur, E. Sennen, and K. V Pantaleon, "Etnomatematika Daerah Manggarai Flores-Ntt Dalam Tradisi Belis Dan Pengukuran," in Seminar Nasional Matematika dan Pendidikan Matematika, 2017, vol. 5, pp. 15-21. 
[5] M. Tamur, E. Sennen, and K. V Pantaleon, "Eksplorasi Etnomatematika Budaya Daerah Manggarai Sebagai Upaya Menggagas Pembelajaran Matematika Berbasis Budaya," in Prosiding Seminar Nasional Pendidikan Matematika UNINUS Bandung, 2016, pp. 69-77.

[6] A. M. Hasibuan, S. Saragih, and Z. Amry, "Development of Learning Materials Based on Realistic Mathematics Education to Improve Problem Solving Ability and Student Learning Independence," Int. Electron. J. Math. Educ., vol. 14, no. 1, pp. 243-252, 2019, doi: 10.29333/iejme/4000.

[7] M. Tamur, "Pembelajaran Kooperatif Tipe STAD Berbasis Etnomatematika Sebagai Upaya Meningkatkan Kemampuan Pemahaman Dan Komunikasi Matematis Mahasiswa PGSD: Mengintegrasikan Tarian Caci Ke Dalam Bahan Ajar Di STKIP St Paulus Ruteng-Flores NTT," Universitas Pendidikan Indonesia, 2012.

[8] A. L. Son, D. Darhim, and S. Fatimah, "Students' Mathematical Problem-Solving Ability Based on Teaching Models Intervention and Cognitive Style," J. Math. Educ., vol. 11, no. 2, pp. 209-222, 2020, doi: 10.22342/jme.11.2.10744.209-222.

[9] M. Saleh, R. C. I. Prahmana, M. Isa, and Murni, "Improving the reasoning ability of elementary school student through the Indonesian realistic mathematics education," J. Math. Educ., vol. 9, no. 1, pp. 41-53, 2018, doi: 10.22342/jme.9.1.5049.4154.

[10] D. Juandi et al., "The Effectiveness of Dynamic Geometry Software Applications in Learning Mathematics: A Meta- Analysis Study," Int. J. Interact. Mob. Technol., vol. 15, no. 02, pp. 18-37, 2021, doi: 10.3991/ijim.v15i02.18853.

[11] S. Ndiung, N. Dantes, I. M. Ardana, and A. A. I. N. Marhaeni, "Treffinger Creative Learning Model with RME Principles on Creative Thinking Skill by Considering Numerical Ability," Int. J. Instr., vol. 12, no. 3, pp. 731-744, 2019, doi: 10.29333/iji.2019.12344a.

[12] B. Y. Yuniati, A. Armiati, and E. Musdi, "The influence of realistic mathematics education ( RME ) approach with the TANDUR on understanding the concepts and solving mathematical problems on grade 8 in smp negeri 1 pantai cermin," in nternational Conference on Mathematics and Mathematics Education, 2020, pp. 1-8, doi: 10.1088/1742-6596/1554/1/012063.

[13] M. Franzen, "Meta-analysis," in Encyclopedia of Personality and Individual Differences, H. V.
Zeigler and T. . Shackelford, Eds. Springer, Cham, 2020, p. 5925.

[14] M. Tamur and D. Juandi, "Effectiveness of Constructivism Based Learning Models Against Students Mathematical Creative Thinking Abilities in Indonesia: A Meta-Analysis Study," Pervasive Heal. Pervasive Comput. Technol. Healthc., no. 1, pp. 107-114, 2020, doi: 10.4108/eai.12-102019.2296507.

[15] M. Tamur, E. Jehadus, F. Nendi, K. Mandur, and V. Murni, "Assessing the effectiveness of the contextual teaching and learning model on students , mathematical understanding ability: a metaanalysis study," J. Phys. Conf. Ser., vol. 1657, no. 1 , p. 012067,2020 , doi: 10.1088/17426596/1657/1/012067.

[16] M. Tamur, V. S. Kurnila, E. Jehadus, S. Ndiung, J. Pareira, and S. Syaharuddin, "Learning from the Past: Meta-Analysis of Contextual TeachingLearning of the Past Decade," Int. J. Educ. Curric. Appl., vol. 4, no. 1, pp. 1-10, 2021, doi: 10.31764/ijeca.v4i1.3981.

[17] M. Tamur, K. Mandur, and J. Pereira, "Do Combination Learning Models Change The Study Effect Size? A Meta-Analysis Of Contextual Teaching And Learning," J. Educ. Expert, vol. 4, no. 1, pp. 1-9, 2021, doi: 10.30740/jee.v4i1p1-9.

[18] N. Susanti, D. Juandi, and M. Tamur, "The Effect of Problem-Based Learning ( PBL ) Model On Mathematical Communication Skills of Junior High School Students - A Meta-Analysis Study," JTAM (Jurnal Teor. dan Apl. Mat., vol. 4, no. 2, pp. 145154, 2020, doi: 10.31764/jtam.v4i2.2481.

[19] Suparman, D. Juandi, and M. Tamur, "Review of problem-based learning trends in 2010-2020: A meta-analysis study of the effect of problem-based learning in enhancing mathematical problemsolving skills of Indonesian students," J. Phys. Conf. Ser., vol. 1772, no. 1, p. 012103, 2021, doi 10.1088/1742-6596/1722/1/012103.

[20] Y. Yunita, D. Juandi, M. Tamur, A. M. G. Adem, and J. Pereira, "A meta-analysis of the effects of problem-based learning on students ' creative thinking in mathematics," Beta J. Tadris Mat., vol. 13, no. 2, pp. 104-116, 2020, doi 10.20414/betajtm.v13i2.380.

[21] M. F. B. Paloloang, D. Juandi, M. Tamur, B. Paloloang, and A. M. G. Adem, "Meta Analisis: Pengaruh Problem-Based Learning Terhadap Kemampuan Literasi Matematis Siswa Di Indonesia Tujuh Tahun Terakhir," AKSIOMA J. Progr. Stud. Pendidik. Mat., vol. 9, no. 4, pp. 851- 
864, 2020, doi: 10.24127/ajpm.v9i4.3049.

[22] Suparman, D. Juandi, and M. Tamur, "ProblemBased Learning for Mathematical Critical Thinking Skills : A Meta-Analysis," J. Hunan Univ. (Natural Sci., vol. 48, no. 2, pp. 133-144, 2021.

[23] Y. K. Sari, D. Juandi, M. Tamur, and A. M. G. Adem, "Meta-Analysis: Mengevaluasi Efektivitas Problem Based Learning pada Kemampuan Pemahaman Matematis Siswa," J. Honai Math, vol. 4, no. 1, pp. 1-18, 2021, doi: 10.30862/jhm.v4i1.144.

[24] M. Tamur, D. Juandi, and A. M. G. Adem, "Realistic Mathematics Education in Indonesia and Recommendations for Future Implementation: A Meta-Analysis Study," J. Teor. dan Apl. Mat., vol. 4, no. 1, pp. 17-27, 2020, doi: 10.31764/jtam.v4i1.1786.

[25] M. Demirel and M. Dağyar, "Effects of ProblemBased Learning on Attitude: A Meta-analysis Stud," EURASIA J. Math. Sci. Technol. Educ., vol. 12, no. 8, pp. 2115-2137, 2016, doi: 10.12973/eurasia.2016.1293a.

[26] F. L. Schmidt and J. E. Hunter, Methods of MetaAnalysis: Correcting Error and Bias in Research Findings, Third. 55 City Road, London: 55 City Road, London: SAGE Publications, Ltd, 2015.

[27] M. Tamur and D. Juandi, "Effectiveness of Constructivism Based Learning Models Against Students Mathematical Creative Thinking Abilities in Indonesia: A Meta-Analysis Study," in Mathematics, Science, and Computer Science Education International Seminar, MSCEIS 2019, 2020 , pp. $1-8$, doi: 10.4108/eai.12-102019.2296507.

[28] D. Juandi and M. Tamur, Pengantar Analisis Meta, 1st ed. Bandung, Indonesia: UPI PRESS, 2020.

[29] M. Tamur, Y. S. Kusumah, D. Juandi, T. T. Wijaya, A. Nurjaman, and A. O. Samura, "Hawthorne effect and mathematical software based learning: A metaanalysis study," J. Phys. Conf. Ser., vol. 1806, no. 1 , p. 012072, 2021, doi: 10.1088/17426596/1806/1/012072.

[30] M. Tamur, E. Jehadus, H. R. P. Negara, M. D. Siagian, M. Marzuki, and R. Sulastri, "Pembelajaran Selama Krisis COVID - 19: Meta Analisis dari Sudut Hasil Belajar yang Diukur," J. Ris. Teknol. dan Inov. Pendidik., vol. 4, no. 1, pp. 101-108, 2021, doi: 10.36765/jartika.v4i1.413.

[31] T. D. Pigott, Advances in Meta-Analysis. Springer New York Dordrecht Heidelberg London, 2012.
[32] R. Yilmaz, "Prospective Mathematics Teachers' Cognitive Competencies on Realistic Mathematics Education," J. Math. Educ., vol. 11, no. 1, pp. 1744, 2020, doi: 10.22342/jme.11.1.8690.17-44.

[33] M. L. McHugh, "Lessons in biostatistics interrater reliability : the kappa statistic," Biochem. Medica, vol. 22, no. 3, pp. 276-282, 2012, doi: 10.11613/BM.2012.031.

[34] L. Cohen, L. Manion, and K. Morrison, Research Methods in Education, 8th ed. Routledge Taylor \& Francis Group, 2018.

[35] T. D. Pigott and J. R. Polanin, "Methodological Guidance Paper: High-Quality Meta-Analysis in a Systematic Review,"Rev. Educ. Res., vol. 90, no. 1, pp. 24-46, 2020, doi: 10.3102/0034654319877153.

[36] M. Borenstein, L. V Hedges, J. P. T. Higgins, and H. R. Rothstein, Introduction to Meta-Analysis, no. January. A John Wiley and Sons, Ltd., Publication, 2009.

[37] S. Park and S. Hong, "The empirical review of meta-analysis published in Korea," Asia Pacific Educ. Rev., vol. 17, no. 2, pp. 313-324, 2016, doi: 10.1007/s12564-016-9433-X.

[38] M. Tamur, D. Juandi, and Y. S. Kusumah, "The Effectiveness of the Application of Mathematical Software in Indonesia: A Meta-Analysis Study," Int. J. Instr., vol. 13, no. 4, pp. 867-884, 2020, doi 10.29333/iji.2020.13453a.

[39] B. Mullen, P. Muellerleile, and B. Bryant, "Cumulative meta-analysis: A consideration of indicators of sufficiency and stability," Personal. Soc. Psychol. Bull., vol. 27, no. 11, pp. 1450-1462, 2001, doi: 10.1177/01461672012711006.

[40] S. Arik and M. Yilmaz, "The effect of constructivist learning approach and active learning on environmental education: A meta-analysis study," Int. Electron. J. Environ. Educ., vol. 10, no. 1, pp. 44-84, 2020, [Online]. Available: https://files.eric.ed.gov/fulltext/EJ1239355.pdf. 